1 Modelling understorey dynamics in temperate forests under

2 global change- challenges and perspectives

$3 \quad{ }^{1,{ }^{*} \text { Landuyt, D., }}{ }^{1,2}$ Perring, M. P., ${ }^{3}$ Seidl, R., ${ }^{4}$ Taubert, F., ${ }^{5}$ Verbeeck, H., ${ }^{1}$ Verheyen, K.

${ }^{1}$ Forest \& Nature Lab, Department of Forest and Water Management, Ghent University, Geraardsbergsesteenweg 267, 9090 MelleGontrode, Belgium

${ }^{2}$ Ecosystem Restoration and Intervention Ecology Research Group, School of Biological Sciences, The University of Western Australia, 35 Stirling Highway, Crawley WA 6009, Australia

${ }^{3}$ Institute of Silviculture, Department of Forest- and Soil Sciences, University of Natural Resources and Life Sciences (BOKU), Peter Jordan Straße 82, 1190 Vienna, Austria

${ }^{4}$ Department of Ecological Modelling, Helmholtz Centre for Environmental Research - UFZ, Permoserstraße 15, 04318 Leipzig, Germany

${ }^{5}$ Computational and Applied Vegetation Ecology (CAVELab), Department of Applied Ecology and Environmental Biology, Ghent University, Coupure Links 653, 9000 Ghent, Belgium

*Corresponding author (dries.landuyt@ugent.be)

\title{
Abstract
}

The understorey harbours a substantial part of vascular plant diversity in temperate forests and plays an important functional role, affecting ecosystem processes such as nutrient cycling and overstorey regeneration. Global change, however, is putting these understorey communities on trajectories of change, potentially altering and reducing their functioning in the future. Developing mitigation strategies to safeguard the diversity and functioning of temperate forests in the future is challenging and requires improved predictive capacity. Process-based models that predict understorey community composition over time, based on first principles of ecology, have the potential to guide mitigation endeavours but such approaches are rare. Here, we review fourteen understorey modelling approaches that have been proposed during the last three decades. We evaluate their inclusion of mechanisms that are required to predict the impact of global change on understorey communities. We conclude that none of the currently existing models fully accounts for all processes that we deem important based on empirical and experimental evidence. Based on this review, we contend new models are needed to project the complex impacts of global change on forest understoreys. Plant functional traits should be central to such future model developments, as they drive community assembly processes and provide valuable information on the functioning of the understorey. Given the important role of the overstorey, a coupling of understorey models to overstorey models will be essential to predict the impact of global change on understorey composition and structure, and how it will affect the functioning of temperate forests in the future. 
Multiple environmental pressures are threatening ecosystems, their functioning and the services they provide (MA, 2005). Although climate change and land cover change are the ones most visible at the global scale (e.g., via large scale deforestations, urbanization, shrinking glaciers and forest fires), also lesspronounced pressures, including subtle changes in temperature and precipitation regimes, deposition of anthropogenically fixed nitrogen and changes in ecosystem management are posing a serious threat. Substantial research effort has been invested into quantifying how these environmental pressures have changed over time and how they will change in the near future (e.g. Alkama and Cescatti, 2016; IPCC, 2014; Meiyappan et al., 2014; Seto et al., 2012). The next step, identifying how these pressures have affected ecosystems in terms of biodiversity (Didham et al., 2007), biotic interactions (Tylianakis et al., 2008) and ecosystem functioning (Balvanera et al., 2006), however, remains challenging (Franklin et al., 2016). The same holds for predicting future effects (e.g. Thom et al., 2017; Sala et al., 2000). Both tasks are complicated by potential interactions among global change drivers, potentially obscuring ecosystem responses to single pressures (Perring et al., 2016; Tylianakis et al., 2008).

Both statistical and process-based modelling can support these efforts by disentangling the effects of environmental pressures on ecosystems. Statistical models are predominantly suited to evaluate past impacts of global change, and can tell us how well-documented ecosystem changes correlate with environmental changes (Seidl et al., 2011a). Moreover, by analysing data gathered along different, preferably orthogonal, environmental gradients, the scope of statistical modelling can be further extended towards estimating how interactions among environmental change drivers have influenced ecosystem properties (Verheyen et al., 2017). However, since statistical models are always fit to a specific context, represented by the data used for modelling, they are less suited to predict future impacts or to explore the outcomes of alternative scenarios, especially if those scenarios involve new combinations of environmental conditions not observed in the past. For those tasks, process-based models are more suited (Seidl, 2017). By coupling processes at multiple temporal and spatial scales, scenario analyses, sensitivity analyses and experimentation in silico can provide an improved understanding of the underlying mechanisms and potential effects of global change (e.g. Cramer et al., 2001; Seidl et al., 2014).

Decades of progress in community ecology and mathematical modelling in combination with increasing data availability have led to the development of numerous process-based models for a wide variety of vegetation types (Jorgensen, 2011). Efforts, however, are not distributed equally across vegetation types. Although most biomes of the world are addressed in process-based modelling, models mostly focus on the dominant species group or growth form within these biomes, assuming that their dynamics are what drives the overall dynamics of the ecosystem. Most grassland and forest models, for example, focus exclusively on herbaceous plants and trees, respectively (Porté et al., 2002; Taubert et al., 2012). For some systems, such as savanna 
ecosystems, where both woody vegetation and herbaceous plants are jointly determining ecosystem dynamics, models already include multiple growth forms (e.g. Tietjen et al., 2016; Simioni et al., 2000).

In principle, the same holds for temperate forests, where understorey communities, including shrubs, herbs, grasses and small trees, influence ecosystem dynamics through their effect on nutrient cycling and tree regeneration (Gilliam, 2007). Nonetheless, understorey communities are frequently ignored in models of temperate forest dynamics, possibly because their functional role remains widely underestimated (Gilliam, 2007). Consequently, efforts to model understorey dynamics have been scarce. The absence of models for these communities makes it hard to predict their future response to global change and to estimate the potential mediating role of the tree canopy (e.g. De Frenne et al., 2013; Verheyen et al., 2012). This extra layer of complexity, literally, means that extrapolating results from models designed for other vegetation types, such as grasslands, is not necessarily a valid solution. Given the fact that understorey communities react to global change (e.g. Bernhardt-Römermann et al., 2015; De Frenne et al., 2015; Verheyen et al., 2012) and play an important role in forest ecosystems (Gilliam, 2007), the inability to predict their future dynamics constitutes an important research gap.

In this paper, we review fourteen published understorey models and consider their design in the context of the processes required to predictively model the composition and structure of forest understoreys under global change. We start with a description of the reviewed models in section 2 . In section 3 , we present a conceptual model that catalogues variables and pathways that are deemed important to predict the impacts of global change on forest understoreys. In section 4, we evaluate to what extent and in what way existing models account for these variables and pathways. Finally, we outline how next generation models could advance the state-of-the-art of forest understorey modelling.

\section{Review of understorey models}

Through a Web Of Science title search (search string: ("ground vegetation" OR understor* OR (forest AND herb*)) AND (model* OR predict* OR simulat*)), we compiled an overview of studies modelling the dynamics of understorey communities, published during the last three decades. This query resulted in a list of 132 publications in September 2017. Lit This set was subsequently amended by scanning reference lists for additional relevant publications. This procedure led to the identification of 14 understorey models, each described in one or more publications (Table 1). Although we focus on process-based models, most of these models made use of empirical modelling techniques as well. 


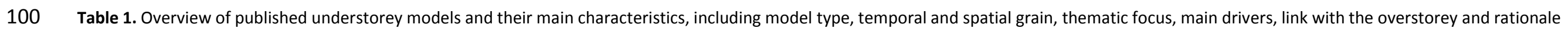

101 for model development. Model types are elucidated in the main text. NA indicates missing information.

\begin{tabular}{|c|c|c|c|c|c|c|c|c|}
\hline Reference & Model type & $\begin{array}{l}\text { Temporal } \\
\text { grain }\end{array}$ & $\begin{array}{l}\text { Spatial } \\
\text { grain }\end{array}$ & Thematic representation of the understorey & $\begin{array}{l}\text { Understorey } \\
\text { drivers }\end{array}$ & Overstorey drivers & $\begin{array}{l}\text { Overstorey } \\
\text { representation }\end{array}$ & Model aim \\
\hline $\begin{array}{l}\text { Kellomäki and } \\
\text { Väisänen (1991) }\end{array}$ & $\begin{array}{l}\text { Logistic growth } \\
\text { curves }\end{array}$ & 1 year* & $100 \mathrm{~m}^{2 *}$ & $\begin{array}{l}\text { Biomass of three PFTs (pioneer, intermediate } \\
\text { and climax species) }\end{array}$ & $\begin{array}{l}\text { Overstorey, } \\
\text { Soil }\end{array}$ & $\begin{array}{l}\text { Climate, } \mathrm{N} \text { deposition, } \\
\text { forest management }\end{array}$ & $\begin{array}{l}\text { Individual- } \\
\text { based tree } \\
\text { growth model }\end{array}$ & $\begin{array}{l}\text { Methodological } \\
\text { advances }\end{array}$ \\
\hline Nabuurs (1996) & $\begin{array}{l}\text { Logistic growth } \\
\text { curves }\end{array}$ & 1 month & $400 \mathrm{~m}^{2}$ & $\begin{array}{l}\text { Biomass of seven understorey species } \\
\text { (Agrotis capillaris, Calluna vulgaris, } \\
\text { Deschampsia flexuosa, Molina Caerulea, } \\
\text { Pteridium aquilinum, Vaccinium myrtillus, } \\
\text { Vaccinium vitis-idaea) }\end{array}$ & Overstorey & NA & NA & $\begin{array}{l}\text { Habitat } \\
\text { modelling }\end{array}$ \\
\hline $\begin{array}{l}\text { Kupferschmid and } \\
\text { Bugmann (2005) }\end{array}$ & $\begin{array}{l}\text { Rule-based } \\
\text { model }\end{array}$ & 1 year & $<1 \mathrm{~m}^{2}$ & Cover of 25 microsite types & Overstorey & $\begin{array}{l}\text { Natural disturbance, } \\
\text { understorey }\end{array}$ & $\begin{array}{l}\text { Rule-based } \\
\text { model }\end{array}$ & $\begin{array}{l}\text { Overstorey } \\
\text { regeneration }\end{array}$ \\
\hline $\begin{array}{l}\text { Muukkonen and } \\
\text { Mäkipää (2006) }\end{array}$ & Empirical model & 1 year & $\begin{array}{l}2 \mathrm{~m}^{2} \\
* * *\end{array}$ & $\begin{array}{l}\text { Biomass of four groups (dwarf shrubs, herbs } \\
\text { and grasses, mosses and lichens) }\end{array}$ & $\begin{array}{l}\text { Overstorey, } \\
\text { soil, climate }\end{array}$ & NA & NA & $\begin{array}{l}\text { Predicting } \\
\text { carbon budgets }\end{array}$ \\
\hline $\begin{array}{l}\text { Khanina et al. } \\
\text { (2007) }\end{array}$ & $\begin{array}{l}\text { Rule-based } \\
\text { model }\end{array}$ & 1 year & NA & $\begin{array}{l}\text { Species presence/absence of six plant } \\
\text { communities }\end{array}$ & $\begin{array}{l}\text { Overstorey, } \\
\text { soil }\end{array}$ & $\begin{array}{l}\text { Climate, forest } \\
\text { management }\end{array}$ & $\begin{array}{l}\text { Individual- } \\
\text { based tree } \\
\text { growth model }\end{array}$ & $\begin{array}{l}\text { Predicting } \\
\text { understorey } \\
\text { composition }\end{array}$ \\
\hline $\begin{array}{l}\text { Vospernik et al. } \\
\text { (2007) }\end{array}$ & Empirical model & 5 year** & $\begin{array}{l}707 \mathrm{~m}^{2} \\
* * *\end{array}$ & $\begin{array}{l}\text { Cover of nine vegetation classes (graminoids, } \\
\text { ferns, herbs, Vaccinium spp, Rubus spp, } \\
\text { ferns, shrubs, deciduous trees and conifers) }\end{array}$ & $\begin{array}{l}\text { Overstorey, } \\
\text { soil }\end{array}$ & Forest management & $\begin{array}{l}\text { Individual- } \\
\text { based tree } \\
\text { growth model }\end{array}$ & $\begin{array}{l}\text { Habitat } \\
\text { modelling }\end{array}$ \\
\hline $\begin{array}{l}\text { Winkler and } \\
\text { Heinken (2007) }\end{array}$ & $\begin{array}{l}\text { Demographic } \\
\text { model }\end{array}$ & 1 year & $25 \mathrm{~cm}^{2}$ & $\begin{array}{l}\text { Number of individuals of single species } \\
\text { (Melampyrum pratense) }\end{array}$ & Climate & NA & NA & $\begin{array}{l}\text { Understanding } \\
\text { understorey } \\
\text { dynamics }\end{array}$ \\
\hline $\begin{array}{l}\text { Popovic and } \\
\text { Lindquist (2010) }\end{array}$ & $\begin{array}{l}\text { Physiological } \\
\text { model }\end{array}$ & 1 day & $\begin{array}{l}\text { Individu } \\
\text { al plants }\end{array}$ & $\begin{array}{l}\text { Biomass of two species (Scilla bifolia, Arum } \\
\text { macalatum) }\end{array}$ & $\begin{array}{l}\text { Overstorey, } \\
\text { climate }\end{array}$ & NA & NA & $\begin{array}{l}\text { Methodological } \\
\text { advances }\end{array}$ \\
\hline $\begin{array}{l}\text { Belyazid et al. } \\
\text { (2011) }\end{array}$ & Semi-empirical & 1 month & $1 \mathrm{~m}^{2}$ & $\begin{array}{l}\text { Cover of five indicator species (Sphagnum } \\
\text { mosses, Vaccinium myrtillus, Deschampsia } \\
\text { flexuosa, Blechnum spicant, Origanum } \\
\text { vulgare) }\end{array}$ & $\begin{array}{l}\text { Overstorey, } \\
\text { soil }\end{array}$ & $\begin{array}{l}\text { Climate, Forest } \\
\text { management, } \mathrm{N} \\
\text { deposition }\end{array}$ & $\begin{array}{l}\text { Biogeochemical } \\
\text { tree growth } \\
\text { model }\end{array}$ & $\begin{array}{l}\text { Predicting } \\
\text { understorey } \\
\text { composition }\end{array}$ \\
\hline $\begin{array}{l}\text { Matejicek et al. } \\
\text { (2011) }\end{array}$ & $\begin{array}{l}\text { Differential } \\
\text { equation model }\end{array}$ & $\begin{array}{l}\text { Continuous } \\
\text { time }\end{array}$ & $1 \mathrm{~m}^{2}$ & $\begin{array}{l}\text { Density of four species (Avanella flexuosa, } \\
\text { Calamgrostis villosa, Vaccinium myrtillus and } \\
\text { Picea abies seedlings) }\end{array}$ & $\begin{array}{l}\text { Overstorey, } \\
\text { soil, } \\
\text { topography }\end{array}$ & NA & Static & $\begin{array}{l}\text { Overstorey } \\
\text { regeneration }\end{array}$ \\
\hline
\end{tabular}




\begin{tabular}{|c|c|c|c|c|c|c|c|c|}
\hline $\begin{array}{l}\text { Dahlgren and } \\
\text { Ehrlén (2012) }\end{array}$ & $\begin{array}{l}\text { Demographic } \\
\text { model }\end{array}$ & 1 year & $25 \mathrm{~m}^{2}$ & $\begin{array}{l}\text { Number of individuals of single species } \\
\text { (Actaea spicata) }\end{array}$ & Soil & NA & NA & $\begin{array}{l}\text { Understanding } \\
\text { understorey } \\
\text { dynamics }\end{array}$ \\
\hline Meen et al. (2012) & Empirical model & 1 year & $\begin{array}{l}\text { Individu } \\
\text { al plants }\end{array}$ & $\begin{array}{l}\text { Indicators of plant performance for a single } \\
\text { species (Cornus suecica) }\end{array}$ & $\begin{array}{l}\text { Overstorey, } \\
\text { soil }\end{array}$ & Climate & $\begin{array}{l}\text { Individual- } \\
\text { based tree } \\
\text { growth model }\end{array}$ & $\begin{array}{l}\text { Methodological } \\
\text { advances }\end{array}$ \\
\hline $\begin{array}{l}\text { Thrippleton et al. } \\
\text { (2016) }\end{array}$ & $\begin{array}{l}\text { Logistic growth } \\
\text { curves }\end{array}$ & 1 year & $625 \mathrm{~m}^{2}$ & $\begin{array}{l}\text { Biomass of five PFTs: grasses, tall forbs, small } \\
\text { herbs, ferns and shrubs }\end{array}$ & $\begin{array}{l}\text { Overstorey, } \\
\text { soil, climate }\end{array}$ & $\begin{array}{l}\text { Climate, natural } \\
\text { disturbance, } \\
\text { understorey }\end{array}$ & $\begin{array}{l}\text { Individual- } \\
\text { based tree } \\
\text { growth model }\end{array}$ & $\begin{array}{l}\text { Overstorey } \\
\text { regeneration }\end{array}$ \\
\hline Thom et al. (2017) & Empirical model & 1 year & $\begin{array}{l}625 \mathrm{~m}^{2} \\
* * *\end{array}$ & $\begin{array}{l}\text { Vascular plant species richness up to } 60 \mathrm{~cm} \\
\text { in height }\end{array}$ & $\begin{array}{l}\text { Overstorey, } \\
\text { climate }\end{array}$ & $\begin{array}{l}\text { Climate, natural } \\
\text { disturbance }\end{array}$ & $\begin{array}{l}\text { Individual- } \\
\text { based tree } \\
\text { growth model }\end{array}$ & $\begin{array}{l}\text { Predicting } \\
\text { understorey } \\
\text { composition }\end{array}$ \\
\hline
\end{tabular}

102 *Information retrieved from Botkin et al. (1972)

$103 * *$ Information retrieved from Monserud and Sterba (1996)

$104 * * *$ Corresponds to the plot size used for gathering data in the field 
Our review of the literature illustrates that modelling understorey communities and how they develop over time has been a topic of interest for at least 25 years. However, modelling attempts are relatively scarce when contrasted with the high number of empirical studies, including both experimental (e.g. De Frenne et al., 2015; Maes et al., 2014) and resurvey studies (e.g. Amatangelo et al., 2011; Bernhardt-Römermann et al., 2015; Li and Waller, 2015; Verheyen et al., 2012;), carried out within this research domain.

Although most models documented in the literature were developed independently, many similarities between underlying modelling concepts can be identified (Table 1). Based on these similarities, models can be subdivided into four broad categories: (1) models based on logistic growth curves, (2) rule-based models, (3) demographic models and (4) empirical models. Although we only label the last category as empirical, many of the reviewed models were to some extent based on empiricism. In our categorization, we define empirical models as models that relate system responses to system inputs without any prior information concerning underlying processes or shapes of the equations to be fitted.

The first set of models simulate the mass of one or more understorey species or species groups based on logistic growth functions parameterized with two static parameters: maximum biomass and maximum growth rate (see, for example, Thrippleton et al., 2016). Correction factors are used to account for resource limitations, more specifically, for light limitation (Nabuurs, 1996; Thrippleton et al., 2016) and nutrient limitation (Kellomäki and Väisänen, 1991). The availability of these resources can be derived from the characteristics of the overstorey, dynamically approximated by tree growth models.

Rule-based models, on the other hand, characterize the dynamics of the understorey based on a set of static if-then rules: "If the current vegetation type at time $t$ is $x$, then it will change to vegetation type $y$ at time $t+1$ ". Rules can be either deterministic (Khanina et al., 2007) or probabilistic, e.g., integrated into first order Markov chain models (Kupferschmid and Bugmann, 2005). The if-clause can either depend on the previous state of the vegetation only (Kupferschmid and Bugmann, 2005), hence assuming a predetermined successional pathway, or can take additional environmental variables into account to dynamically simulate shifts in vegetation composition (Khanina et al., 2007).

Demographic models mainly focus on species' life cycles, modelling reproduction rates, numbers of offspring, and seed dispersal (e.g. Meen et al., 2012). Current approaches documented in the literature are limited to modelling the spatial distribution and density of single species (Dahlgren and Ehrlén, 2012; Winkler and Heinken, 2007). Both reviewed studies derived demographic rates from site-specific measurements and did not include competition processes. Therefore, their models can't be expanded towards other systems, especially those wherein multiple species interact.

A final group of models consists of empirical approaches. In these models, relationships between overstorey structure and species composition in the understorey are statically defined, based on empirical data. As a result, understorey changes only occur following a change in the overstorey. Other studies dealt with this 
limitation by considering forest age (Muukkonen and Mäkipää, 2006) or environmental conditions as additional predictors (Thom et al., 2017; Vospernik et al., 2007). In the latter models, predictions of understorey composition can change from year to year, regardless of whether overstorey changes occur.

In addition to these four broad groups of models three other unique modelling approaches have been proposed. Popovic and Lindquist (2010) applied a physiological model, initially developed for crop yield modelling, that explicitly accounts for below- and above-ground competition, and models growth primarily based on photosynthetic rates. Matejicek et al. (2011) used a discrete space, continuous time differential equation model, inspired by diffusion models in physics, to determine the spatial spread of understorey species taking into account a range of environmental factors. A final approach, developed by Belyazid et al. (2011), makes use of response functions, which represent the response of individual species to a range of environmental factors, not taking into account competition with other understorey species. By comparing species-level responses derived from these response curves the available space is distributed among all competing species. To account for time lags, an additional parameter, inversely related to a species' lifespan, is included.

The temporal resolution of the reviewed models is, apart from some exceptions (Matejicek et al., 2011; Popovic and Lindquist, 2010), widely congruent. Timesteps were generally set to one year, i.e., a single growing season. The popularity of this timestep is most likely related to the popularity of one-year-timesteps in tree growth models (Bugmann, 2001). Model coupling is facilitated considerably by applying the same timestep for understorey and overstorey growth. Similarly, but less frequently, spatial resolution is determined by the overstorey models used, with grains typically ranging between 25 and $1000 \mathrm{~m}^{2}$ (e.g. Nabuurs, 1996; Thrippleton et al., 2016). Within these grid cells, models assume uniform abiotic conditions and, consequently, a uniform understorey composition. Less than half of the reviewed models focused on individual plants, or opted for smaller grain sizes of approximately $1 \mathrm{~m}^{2}$.

The level of detail of the model output, also referred to as the model's thematic resolution, was again largely comparable among models. The reviewed models either simulated the dynamics of a single species, multiple species or a limited set of species groups, referred to as plant functional types (PFTs). These differences were largely explained by the aim of the model. Single species models aimed at understanding a species' population dynamics (Dahlgren and Ehrlén, 2012; Winkler and Heinken, 2007), while multiple species models or PFT-based models aimed at predicting community composition, either in terms of indicator species (Belyazid et al., 2011) or in terms of a community's functional characteristics (Muukkonen and Mäkipää, 2006; Thrippleton et al., 2016; Vospernik et al., 2007). Species or species groups were either represented in terms of numbers of individuals or in terms of biomass. Modelled species include either indicator species or functionally important species, i.e. species that are expected to influence overstorey regeneration, such as Pteridium aquilium, Deschampsia flexuosa, Vaccinium spp and Rubus spp (e.g. Fotelli et al., 2002; Harmer and Morgan, 2007; Petriţan et al., 2012; Parker et al., 2009). 
Overall, we found substantial variation among existing understorey models in terms of model concepts and the level of detail taken into account. Although differences among models can often be attributed to differences in research objectives, this was not generally the case for the reviewed understorey models. Different objectives were tackled with similar modelling approaches and vice versa. In general, understorey modelling was either driven by the need to appraise the influence of understorey growth on overstorey regeneration (Kupferschmid and Bugmann, 2005; Matejicek et al., 2011; Thrippleton et al., 2016), to understand understorey community assembly or population dynamics (e.g. Winkler and Heinken, 2007), to predict forage supply over time (e.g. Nabuurs et al., 1996) or to predict understorey diversity (e.g. Thom et al., 2017).

\section{A process-based perspective on forest understorey dynamics}

Nearly all of the models documented in the literature are based on simplified mathematical concepts that are successful in reproducing patterns of understorey dynamics for the case studies under investigation. It remains questionable, however, whether their results can be extrapolated to new environmental conditions and whether they can predict alternative properties of understory communities, such as, community trait values and distributions. These features are of crucial importance when effects of global change on the understorey are to be identified in terms of composition, structure and functioning. For this purpose, more process-based approaches are needed.

Although such models have already been proposed for other vegetation types (Jørgensen et al., 2011), they might not be readily applicable for understoreys. While the dynamics of understorey species and their communities are driven by similar ecological processes as those observed in other vegetation types (e.g. growth, mortality, competition), resources and conditions that support these processes differ considerably in a forest compared to, for instance, a grassland system. Instead of being driven primarily by climate (e.g. irradiation, annual mean temperature, precipitation), soil conditions (e.g. nutrient content, water availability) and neighbouring competitors, resources and conditions for understorey plants are filtered by the forest environment (Figure 1), leading to altered resource levels and dynamics, potentially requiring different modelling routines to account for them.

Below we discuss how the forest environment affects resources and conditions for understorey growth, focussing on those aspects that are characteristic for the forest environment: the presence of an overstorey, a litter layer, tree roots, disturbances with varying frequency and severity and potential legacies of past (agricultural) land use. We focus here on temperate deciduous forests, dominated by tree species that shed their leaves during winter, giving rise to a dynamic light environment throughout the year. The litter layer in these forests consists predominantly of quickly decomposing leaves and woody debris. Water is abundantly available and soils are relatively fertile due to the yearly supply of organic matter. In these forests, 80 to 90 

seedlings (Gilliam, 2007).
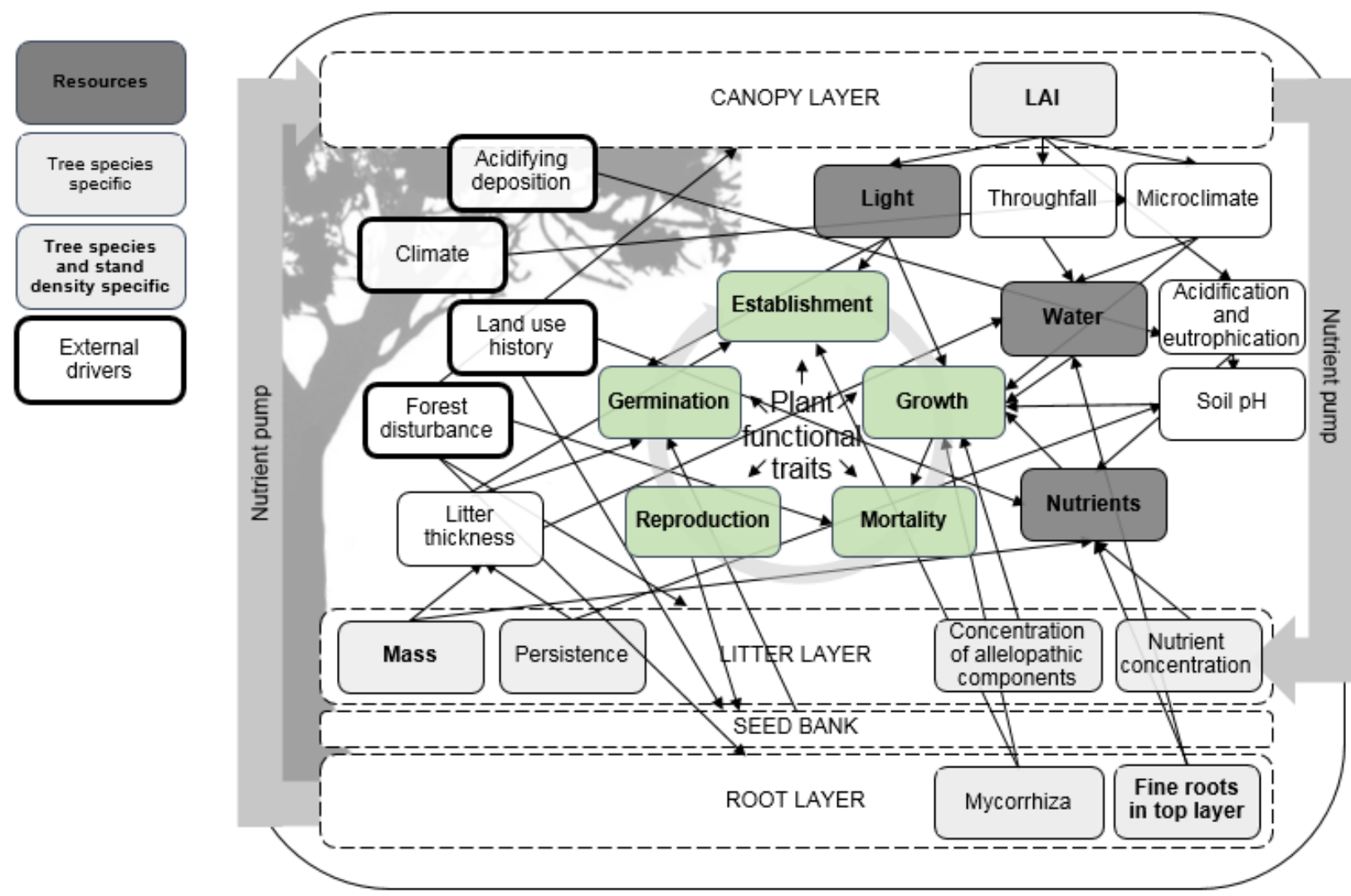

Figure 1. Schematic overview of the most important mechanisms that influence understorey community dynamics in temperate forests, with a focus on mechanisms that act at the local scale. Landscape influences were not included.

The tree canopy and its impact on light availability is probably one of the most studied factors in forest ecology, specifically in relation to tree regeneration (Lieffers et al., 1999). The canopy layer modifies light that reaches the forest floor in two ways: (1) the canopy lowers the amount of light, and hence modifies the pattern of light availability, and (2) it changes the ratio between the red and infrared spectrum of the light, also referred to as the quality of light.

Due to the phenological cycles of the overstorey, light availability and quality vary throughout the year. These phenological cycles have given rise to the adoption of contrasting strategies by forest understorey species, ranging from light-demanding species that fulfil their life cycle before tree budburst in spring to shadetolerant species that are able to grow in a low light environment during the rest of the growing season. These differences in temporal niches are an important mechanism explaining species co-occurrence in understorey communities (Bratton, 1976). In the light of climate change, which is expected to modify seasonal patterns of temperature and precipitation (IPCC, 2014) as well as impact phenological processes, also strategy-specific responses of forest understorey species can be expected due to shifting temporal niches. In addition to 
seasonal light dynamics the canopy further modifies diurnal light dynamics. In a closed forest, only a small fraction of total daily irradiation reaches the forest floor, predominantly as diffuse light. During several short periods, also direct irradiation reaches the forest floor. These so-called sun flecks are generally scarce, but often responsible for a large portion of the total amount of light that reaches the forest floor and, hence, for a large share of carbon that is assimilated by the understorey (Chazdon and Pearcy, 1991; Way and Pearcy, 2012). This share, however, depends on the number and the size of sun flecks which, in turn, depend on the canopy structure. Many small sun flecks, for example, are assumed less important for understorey growth than one large sun fleck (Lieffers et al., 1999). Although the influence of canopy structure on the partitioning between direct and diffuse irradiation has been studied, it has rarely been included in process-based vegetation models (Way and Pearcy, 2012).

Light quality, on the other hand, refers to the ratio between the red and far red spectrum of light. After overstorey leaf flushing, this ratio is lowered from 1.2 (equivalent to open field conditions) to around 0.2 at the forest floor, a value which varies with overstorey tree species composition (Daws et al., 2002; VazquezYanes et al., 1990). As germination is known to be highly dependent on light quality (Jankowska-Blaszczuk and Daws, 2007), changes in overstorey composition might result in altered germination patterns.

The canopy also influences nutrient availability. In addition to transferring nutrients from the mineral soil to the topsoil via leaf litter production (a process referred to as 'nutrient pump' in Figure 1), the canopy also modifies the input of atmospheric components, which is especially true for nitrogen (e.g. Avila et al., 2017; Fowler et al., 1989). De Schrijver et al. (2007), for example, found that coniferous canopies transfer on average 1.7-times more $\mathrm{NO}_{3}{ }^{-}$and $\mathrm{NH}_{4}{ }^{+}$to the soil than deciduous canopies. This may increase nitrogen availability for the understorey but can also increase soil acidification (De Schrijver et al., 2012) which, in turn, can affect nutrient and base cation availability as well as the availability of aluminium, an element which is toxic for many plant species (Falkengren-Grerup et al., 1995).

The canopy lowers overall water availability by reducing throughfall and alters the distribution of precipitation within a stand, as stemflow concentrates precipitation in the zones surrounding the stems (Staelens et al., 2008, 2006). This is particularly true for tree species with a smooth bark and branches angled upwards, such as European beech (Fagus sylvatica L.). Partitioning between interception, throughfall and stemflow depends on rainfall characteristics, but also on tree species, successional status of the forest, and stand density (Barbier et al., 2009). Deciduous canopies also modify the temporal pattern of incoming precipitation during the year, reducing water availability more strongly during the growing season. This might, for example, lead to an increased impacts of summer droughts as temperature and evaporation rates rise due to climate change (IPCC, 2014). Hence, both climate change and changes in overstorey composition can result in changes in water availability at the forest floor. 
The canopy layer also determines the forest microclimate to a large extent (Barkman, 1992), leading to lower temperatures and reduced wind speed, which are both lowering evaporation rates at the forest floor. Both, the species composition of the overstorey (Porté et al., 2004) and the closure of the canopy (De Frenne et al., 2013) influence the magnitude of this microclimate effect, which can influence water use efficiency and growth of understorey plants. As shown by De Frenne et al. (2013), it is important to include this climate buffering capacity of the overstorey for predicting development trajectories of forest understoreys.

\subsection{The litter layer}

Similar to the canopy, litter modifies the quantity and quality of light available for seeds embedded in or below the litter layer (Vazquez-Yanes et al., 1990). Hence, changes in litter dynamics, such as increased decomposition due to overstorey disturbance or climate change, might promote the germination of more light demanding species, again altering understorey germination patterns.

In temperate forests, the quality of leaf litter produced by the overstorey strongly influences nutrient availability. The total mass of leaf litter and its decomposability both significantly influence the amount of nutrients available for the understorey. As shown by Augusto et al. (2003), the decomposition process predominantly influences the nutrient content of the top layer of the soil, coinciding with the rooting depth of most understorey species.

Leaf litter can also produce organic acids during decomposition (Nilsson et al., 1982). Together with the efficiency of the overstorey to capture acidifying components (see section 3.1), litter quality is considered one of the main driving factors of soil acidification by the overstorey (De Schrijver et al., 2012), and need to be taken into account in process-based models of forest understorey dynamics.

Leaf litter can have a direct negative effect on understorey growth as it can produce chemical components that inhibit understorey growth, generally referred to as allelopathy (Barbier et al., 2008). Tree species composition of the overstorey as well as an understorey species' susceptibility to allelopathic compounds determine whether growth inhibition through allelopathy needs to be taken into account in modelling understorey growth. Next to chemical inhibition, litter may also inhibit understorey growth mechanically. As most seedlings are only able to establish if their roots reach the mineral soil, a thick litter layer may inhibit establishment, mainly for seeds that germinate on top of the litter layer. For seeds that germinate below the litter layer, the ability of the shoot to penetrate the litter layer is crucial for establishment.

Next to these inhibiting effects of litter, the litter layer can also promote establishment, as it conserves soil moisture (Albrecht and McCarthy, 2009; Facelli and Pickett, 1991). Hence, litter may have positive or negative effects on establishment, depending on the environmental conditions and the thickness of the litter layer (Xiong and Nilsson, 1999). Litter, such as coarse woody material, can also act as a substrate itself, promoting the growth of species specifically adapted to these substrate types (e.g. Kumar et al., 2017). 
Trees take up nutrients and water via their root system. Therefore, the presence of tree roots close to the soil surface may lead to competition for nutrients and water with the understorey (Barbier et al., 2008). As tree species differ in root morphology and the vertical distribution of fine roots (Gale and Grigal, 1987), competition for belowground water resources might differ among tree species. There are also seasonal differences in the amount of water extracted from the soil, depending on the photosynthetic activity of the overstorey. In addition, tree roots can also increase water and nutrient availability for the understorey. Some tree species can redistribute water from deep soil layers to drier top layers, generally referred to as hydraulic redistribution (Neumann and Cardon, 2012). Moreover, some tree species fix inorganic nitrogen from the atmosphere, which directly increases nitrogen availability for the understorey. However, this may also increase soil acidity by accelerating nitrification (Van Miegroet and Cole, 1984). Negative effect of soil acidification has been discussed in section 3.1.

A final factor which might influence the performance of understorey plants is the presence of mycorrhizal fungal communities (Uibopuu et al., 2012). As forest age and tree species composition influences mycorrhizal fungal community composition (Lang et al., 2011), this might be an additional pathway of overstorey understorey interaction, worthy to be included in understorey models.

\subsection{Forest disturbances and land use history}

Harvesting activities, storm events, insect outbreaks and forest fires are considered as the most important disturbance events in forests (Seidl et al., 2011b). For understoreys, browsing can be additionally important (Roberts and Gilliam, 2003). Overstorey disturbances often lead to sudden increases of resource availability, resulting in germination of dormant seeds and/or accelerated understorey growth (Battles et al., 2001). Next to influencing resource availability, disturbances can also lead to mortality of understorey plants depending on the severity of the disturbance event and species-specific responses to disturbances (e.g. Abella and Springer, 2015; Zenner and Berger, 2008; Rooney and Waller, 2003). Especially when frequent disturbances occur, species-specific responses can play a dominant role in structuring emerging plant communities (Keith et al., 2007; Noble and Slatyer, 1980). As most forest herbs are perennial and only reach maturity after several years, disturbances can in some cases lead to local extinction of understorey species and are thus important to consider when predicting future understorey composition. When disturbance events have persistent negative effects, such as soil compaction after intensive harvest events (Ampoorter et al., 2012), elevated mortality rates may occur for a longer period of time.

Also past human disturbances, often referred to as a forest's land use history, can affect current resource levels and growing conditions at the forest floor, but also future development trajectories of understorey communities (Perring et al., 2016). Land use history determines, for example, the availability of phosphorus, with high levels of phosphorus in forests established on former agricultural soils with an extensive history of 
fertilization (Flinn and Marks, 2007). The influence of phosphorus on community composition will depend on the environmental conditions and the species under consideration (e.g. Baeten et al., 2009). Next to its influence on phosphorus levels, land use history also determines the composition of the seed bank which will determine community composition after major disturbances that promote germination of dormant seeds.

\section{Mechanistic foundation of existing understorey models}

As discussed above, the forest environment alters the resources and conditions at the forest floor via a diverse set of pathways. These, in turn, affect multiple demographic processes of understorey plants. Here, we assess to what extent and how current models account for these processes (Figure 2).

First of all, there is an imbalanced consideration of resources in existing understorey models. Most studies focus solely on light, while a minority also accounts for water and nutrient limitations (e.g. Belyazid et al., 2011). Studies that do take nutrient limitations into account largely focus on nitrogen availability or use more general proxies, such as site quality indices. None of the reviewed models account for phosphorus limitations, a crucial aspect especially when understorey trajectories in post-agricultural forest sites are considered (Baeten et al., 2009). Similarly, effects of other environmental factors, including microclimate, soil acidity and mycorrhizal fungal communities, are clearly underrepresented in current modelling initiatives.

Second, none of the reviewed models consider the litter layer explicitly. This contrasts with the empirical evidence discussed above. Although it has been shown that the litter layer may affect demographic rates, none of the reviewed models took these relationships explicitly into account.

There is also a clear divide between the reviewed models regarding the processes considered. Understorey models either focus on competition and growth or on germination, establishment, reproduction and mortality (See Figure S1 in Supporting Information). These differences in focal processes result in different model concepts to be used. While the first group mainly considers dynamics in plant biomass, the second group focusses on the number of individual plants.

When looking specifically at the drivers that are accounted for in predicting understorey dynamics, we identified a clear trend. While most models consider the overstorey as one of the most important factors directly determining understorey composition (predominantly through its influence on the light environment), direct influences of global change drivers were considered less frequently. The impact of global change was generally modelled via overstorey changes using a linear model chain, connecting overstorey models to understorey models. First, overstorey dynamics are simulated in response to a series of global change drivers. Next, understorey composition is predicted based on the simulated overstorey which determines the growing conditions for the understorey. Although such a model chain is promising, the way it has been put into practice might be suboptimal. Most of the time, only light is used to describe the conditions at the forest floor, while other resources and conditions are frequently overlooked. 


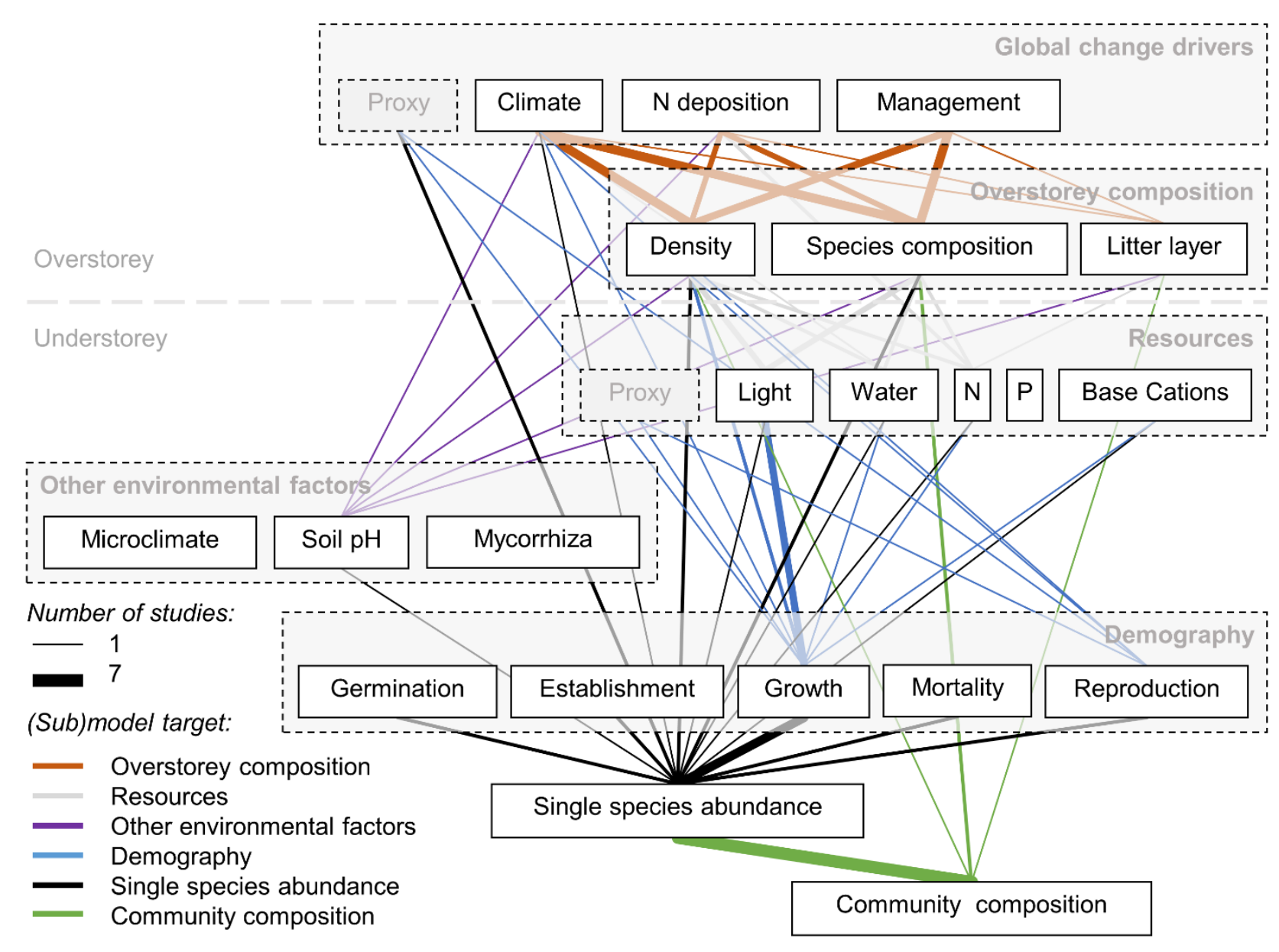

Figure 2. Schematic overview of modelled relationships in the reviewed understorey models. The term (sub)model target refers to processes or state variables that are explicitly predicted by a model or one of its submodels. A proxy refers to an indicator that characterizes multiple state variables at once (e.g. soil quality scores). For more details on individual models, we refer to the Supporting Information (Figure S1).

Although we classified most of the reviewed models as being process-based (because they explicitly model a range of processes), most of the processes they consider are modelled empirically. Growth modelling is, for example, often based on logistic response curves (e.g. Thrippleton et al., 2016). Similarly, demographic rates are usually estimated based on regression models with environmental conditions as predictor variables (e.g. Dahlgren and Ehrlén, 2011). These empirical approaches make extrapolating existing models to new environmental conditions or other species groups inappropriate.

\section{Ways forward for modelling forest understorey}

\section{5.1. Dealing with complexity}

372 In this review, we have highlighted empirical evidence for the influence of a variety of processes on understorey community composition in temperate forests, and document that only a minority of these processes are included in existing understorey models. This, however, does not necessarily mean that existing models cannot predict understorey composition reliably. Numerous vegetation models have shown that not all processes need to be included to achieve good predictive performance (e.g. Fontes et al., 2010). A process 
that has been proven to influence understorey composition in a single factorial experiment, for example, might appear irrelevant when other driving processes are considered as well. Including such a process will not improve model performance. Instead, it will only increase the complexity of the model and the amount of parameters to be estimated. Therefore, models aim at including only the most important processes, i.e. those that are able to influence the system's characteristics of interest.

However, defining the processes that play a dominant role is challenging. While in some cases, one can rely on experts in the field, most of the time inspiration is drawn from existing models and the processes they consider. Most of the reviewed understorey models, for example, were based on modelling concepts that have proven to be successful for other vegetation types. The processes, accounted for by these models, however, are those that are important for the vegetation type they were originally developed for. Although this strategy can be successful by altering the relative importance of the included processes (see, for example, Taubert et al., 2012), we argue that this is a suboptimal approach for understorey modelling, as it might lead to the omission of potentially important processes in understorey dynamics. Furthermore, it is suboptimal because environmental conditions at the forest floor (and their temporal dynamics) aren't comparable to those experienced by other vegetation types. This means the processes and/or the way they need to be modelled might deviate considerably from those included in existing models for other vegetation types such as forest overstorey or grasslands.

Process-based models can help in identifying the most important processes determining understorey dynamics. As a first step, one needs to develop a process-based model that considers those processes that are deemed important based on empirical evidence (as described in section 3). Here, special attention needs to be paid to integrating demographic and physiological processes (Jeltsch et al., 2008). Next, by sensitivity analyses or by comparing model runs that either include or exclude a specific process, the relative importance of individual processes and associated parameters can be revealed. Subsequently, model calibration can focus on these critical processes and parameters, in order to improve model performance.

\subsection{From PFT-based to trait-based approaches}

Modelling changes in community composition involves modelling individual species and changes in their relative abundance. Modelling the entire available species pool of forest understorey plants, however, might be unrealistic. Modellers have overcome this problem by modelling a range of plant functional types (PFTs) that represent the different strategies that occur in the available species pool (Cramer, 1997). One of the main limitations of using PFTs is that at least some strategies that exist in reality will be ignored (Van Bodegom et al., 2012). This is especially problematic for highly diverse understorey communities that harbour a broad range of strategies. Although this issue can be partially addressed by increasing the number of PFTs, this is rarely done as each additional PFT requires a new set of parameters (or even equations) that determine 
its response to the environment. As these parameters are generally derived empirically, increasing the number of PFTs drastically increases data needs.

Alternatively, one can model a PFT's response in a more mechanistic way, by explicitly considering the mechanistic links between plant functional traits and demographic rates, jointly determining its response to the environment (Suding et al., 2008). These plant functional traits are broadly defined, ranging from traits that determine a plant's architecture (e.g. specific leaf area, height), its tissue's chemical composition (e.g. leaf nitrogen content) and its physiological rates (e.g. photosynthetic efficiency) (Violle et al., 2007). In a modelling context, these traits can be used to estimate a broad range of process rates (e.g. growth, dispersal ability, water use) and, hence, the way a PFT will respond to its environment. The main advantage of this trait-based approach is that adding a PFT only requires additional trait values, not extra equations or parameters describing growth and demographics. Realistic combination of trait values can be generated automatically (e.g. Pappas et al., 2016), based on measured trait values in the field, their frequency distributions and correlation structures among them (Diaz et al., 2016; Wright et al., 2004), giving rise to the possibility to increase the number of PFTs considerably. Although we believe that simulations with fixed PFTs are still useful and sometimes the only feasible method to predict responses to global change (e.g. some processes might still require empirical response functions), we advocate implementing mechanistic links between traits and species performance to facilitate upscaling to a larger set of PFTs. Additionally, the outputs generated by trait-based modelling, which can be expressed in terms of community weighted mean trait values and trait ranges, will be better proxies to express the functioning of the understorey and its species richness (Lavorel and Garnier, 2002), compared to those generated by PFT-based modelling.

Next to grouping plant species on a functional basis, one also needs to decide how to group individuals within a specific functional group. Several strategies exist to address this issue. One can either consider all individual plants independently (individual-based modelling), group individuals with identical behaviour to increase computational efficiency (cohort-based modelling), or simply merge all individuals of a specific functional group. Cases where individual-based modelling is preferred are those where a limited number of clearly recognizable individuals need to be modelled. As this is generally not the case for understorey modelling, individual-based approaches might become computationally intractable. This was confirmed by the reviewed models, where individual-based approaches were only used for single species modelling (e.g. Winkler and Heinken, 2007). Cohort-based approaches group individuals based on similar behaviour. In most cases, size classes are used, as these largely determine an individual's competitive performance and growth rate. As intraspecific size differences in understorey communities are rather small, compared to those found in overstorey communities (Bugmann et al., 2001), grouping based on size might be less relevant for this vegetation type. However, also merging all individuals within one functional group is often not preferable. As many understorey plants change their behaviour with age (Bierzychudek, 1982), age-classes might be more relevant. Flowering, seed production and carbon allocation to reserve pools, for example, may depend 
on plant age (Noble and Slatyer, 1980). Hence, we suggest that cohort-based modelling based on age classes could be a promising way to consider when modelling understorey dynamics.

\subsection{Spatial and temporal resolution}

In general, the desired spatial and temporal resolution for models varies depending on the question at hand. However, available options are constrained by the vegetation type of interest. As discussed above, the vegetation period of understorey species may differ from one species to the next. While some species try to fulfil their yearly life cycle before overstorey leaf flush, others are present the year round. These differences in temporal niches mean that the strength of competition between two species likely depends on the day of the year. To be able to explicitly consider these temporal niches, either subannual timesteps or elaborate upscaling procedures need to be used (Harvey, 2000).

The spatial grain of vegetation models is often set to the area wherein individuals are expected to compete for the same resources. Within this area, resources and conditions are assumed to be uniform and locations of individual plants are generally not specified. This simplification, as applied in forest gap models, reduces the complexity of numerical calculations considerably compared to models that calculate competitive interactions spatially explicitly, based on the geographical location of competing individuals and their zones of competitive influence (e.g. Reineking et al., 2006). For understorey modelling a similar approach can be applied. Grain sizes, however, will need to be a lot smaller than those used in forest gap models, preferably ranging between several dozen square centimetres to one square metre. When defining grain sizes for vegetation models, one also needs to consider the spatial heterogeneity of resources and conditions. As this heterogeneity is an important factor that may explain species co-existence (Kumar and Chen, 2017; Tilman, 1982), grain sizes should be able to capture this heterogeneity in order to avoid underestimating diversity on a larger scale. As discussed in section 3, the forest environment not only modifies resource levels but can also increase their spatial heterogeneity, suggesting the need for small grain sizes.

\subsection{Predicting responses to global change}

The next generation of process-based understorey models should be able to predict understorey responses to changes in resources and conditions at the forest floor. Our suggestions above will aid this endeavour. However, the way global change translates to changes in environmental conditions at the forest floor will critically depend on overstorey states and dynamics. The forest overstorey can mediate the impact of global change on understorey diversity and functioning via a broad range of pathways (section 3, Figure 1). Although many of these pathways have the potential to dampen the impacts of global change, others also hold the potential to amplify them. Litter accumulation can, for example, mediate the impact of drought, but can also amplify soil acidification. Whether specific processes will amplify or dampen the impacts of global change will depend on the environmental context, the species considered, and the timeframe of interest. 
Process-based understorey models have the potential to investigate these complex interactions. As a first step, these models can be used to investigate how understorey communities respond to changes in resources and conditions at the forest floor without explicitly modelling the overstorey. Such simulations can provide information on potential interactions among the local drivers of community composition, such as nutrient availability, water availability, light availability and temperature. Using this approach to assess the impact of a specific global change scenario requires selecting trajectories of local drivers that are representative for this global change scenario. This task, however, is far from straightforward. To be able to predict such trajectories one needs to know how global change drivers, often expressed at the regional level, affect the overstorey and how global change together with the overstorey affects the microclimatic conditions and soil characteristics, determining the growing conditions for the understorey. Such predictions can be made by coupling atmospheric models, forest dynamic models and micro-climate models in a hierarchical manner, going from regional changes (climate, acidifying deposition) and stand-level changes (overstorey response to climate change, alternative forest management) to changes in local growing conditions for understorey plants. Coupling this model chain to process-based understorey models can be seen as the next step to predict understorey responses to global change. Subsequently, feedbacks can be added to the model chain, including altered tree regeneration rates through competition between understorey plants and tree seedlings, and soil quality changes through uptake and release of nutrients by the understorey (see also Kupferschmid and Bugmann, 2005; Thrippleton et al., 2016). Modelling these feedbacks will likely improve predictions and provide valuable information on the functional role of the understorey and its importance for long-term forest growth.

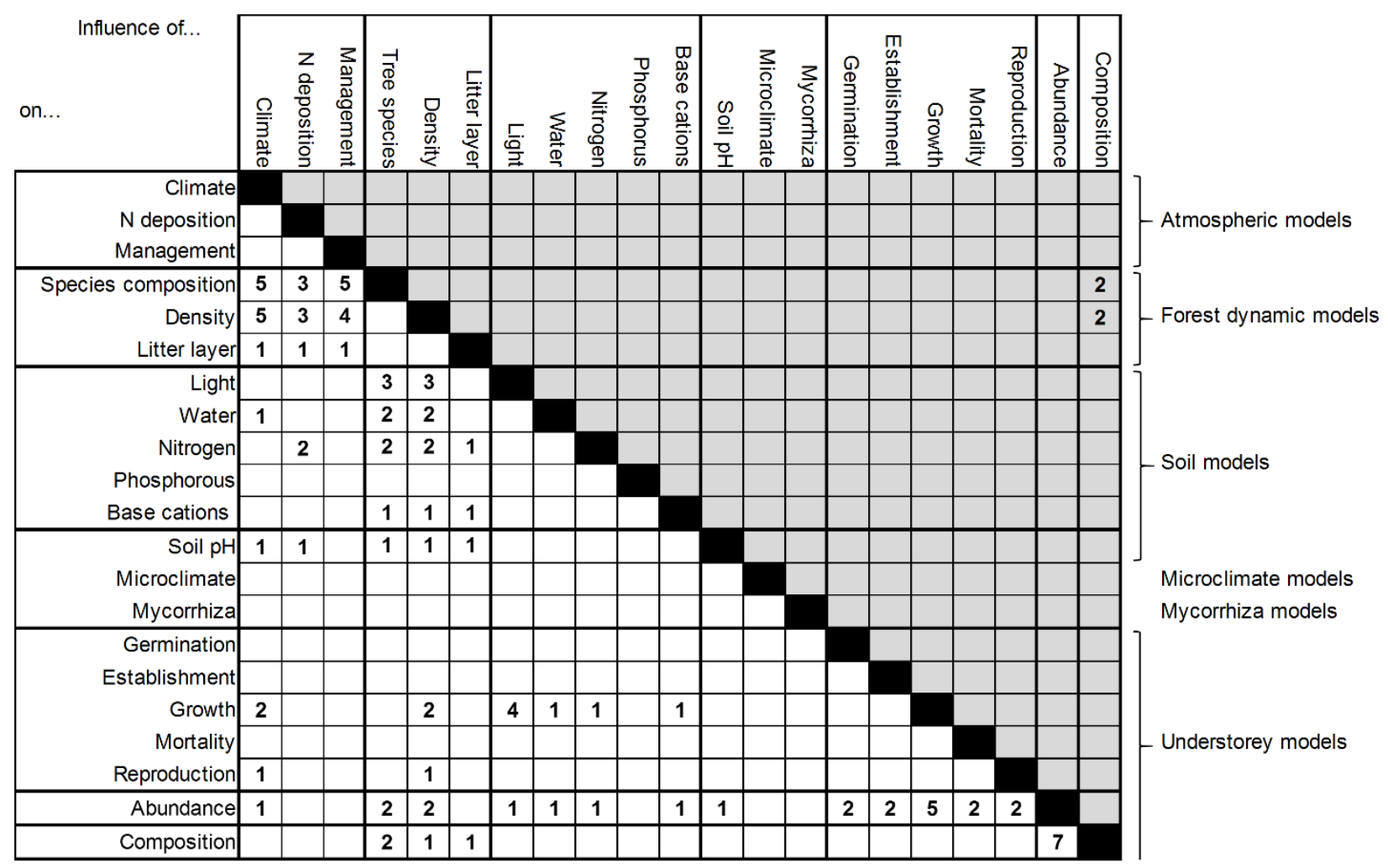


Figure 3. Overview of mechanisms accounted for by the reviewed models. Numbers refer to the number of publications that account for the influence of factor $x$ (column header) on factor $y$ (row header). White grid cells represent top-down interactions, while grey cells refer to bottom-up or feedback mechanisms.

Although some of the reviewed models already combine understorey models with soil and overstorey models to investigate the impact of global change on understorey dynamics, many relationships in this complex process chain have not yet been accounted for in models (Figure 3). Especially the absence of microclimate models can be considered as an important missing link in such a linked modelling framework. Such missing links highlight that in addition to advances in process-based understorey modelling, advances in other research domain are needed to be able to predict the influence of global change on understorey dynamics.

\subsection{Data needs}

In order to develop the next generation of process-based understorey models, the availability of reliable data is crucial. Although data on plant functional traits are becoming increasingly available via online databases (e.g. www.try-db.org), not all traits and species are equally represented (Kattge et al., 2011). While forest overstorey species are well-represented, additional efforts are needed to expand available data on understorey species. Also data on traits that are hard to measure, such as root characteristics, are still scarce (Kattge et al., 2011). In addition to data on individual traits, relationships among traits need to be further investigated, while mechanistic links between traits and process rates need to be demonstrated and measured (see section 5.3). Such data can be gathered via detailed measurements in growth experiments. Finally, data on long-term changes in understorey community composition are needed. These data can be used for model validation, but also for estimating parameter values that can't be measured in the field directly. Such data are being gathered in permanent and quasi-permanent monitoring plots across Europe and North America (see, for example, Verheyen et al., 2012). Long-term global change experiments, focussed on understorey communities, can complement these observational data to attain more representative calibration and validation data sets.

Clearly, process-based modelling of understorey communities will involve combining numerous different data sets. As all these data sets come with their own levels of uncertainty, advanced techniques such as Bayesian data assimilation (Clark, 2005) will be needed to account for these uncertainties when assimilating data into models. This technique will also enable propagating uncertainties through the model, in order to obtain an idea on how data uncertainty affects model output uncertainty.

\section{Conclusions}

Global change is altering the composition of the understorey in temperate forests. Although models have the potential to increase our understanding of the mechanisms that drive these changes and can support the development of mitigation strategies, only a small set understorey models are currently available. The parsimony of these models contrasts with the complexity of the effects of global change described in the 
literature. While most approaches succeed in modelling the impact of one or more global change drivers on at least one community assembly process, none of them adopts a fully integrative approach, which would enable us to assess the (interactive) effects of multiple global change drivers on the composition, structure and functioning of the understorey. We contend that such an integration can be achieved by modelling the dynamics of individual species and interactions among them in a more process- and trait-based manner. One way to start this model development process is by focussing on those processes that have been found to influence understorey community development. Next, through simulation and sensitivity analyses, complexity can be reduced before data-based calibration takes place on retained, critical processes and parameters. To be able to predict the understorey's response to global change, special attention needs to be paid to the overstorey, which has the potential to modulate the effects of global change. Hierarchical modelling, combining overstorey models and understorey models, should be considered to deal with this extra layer of complexity.

\section{Declaration of interest}

The authors declare that they have no conflict of interest.

\section{Acknowledgements}

We thank the European Research Council for funding this research through the PASTFORWARD project (ERC Consolidator Grant: 614839). DL is supported by a postdoctoral fellowship of the Research FoundationFlanders (FWO). RS acknowledges support from the Austrian Science Fund FWF through START grant Y895B25. We also thank two anonymous reviewers for their valuable input.

\section{References}

Abella, S. R., \& Springer, J. D. (2015). Effects of tree cutting and fire on understory vegetation in mixed conifer forests. Forest Ecology and Management, 335, 281-299. http://doi.org/10.1016/j.foreco.2014.09.009

Albrecht, M. A., \& McCarthy, B. C. (2009). Seedling establishment shapes the distribution of shade-adapted forest herbs across a topographical moisture gradient. Journal of Ecology, 97(5), 1037-1049.

Alkama, R., \& Cescatti, A. (2016). Biophysical climate impacts of recent changes in global forest cover. Science, 351(6273), 600-604.

Amatangelo, K. L., Fulton, M. R., Rogers, D. A., \& Waller, D. M. (2011). Converging forest community threatens landscape-level diversity. Diversity and Distributions, 17, 201-213.

Ampoorter, E., De Schrijver, A., Van Nevel, L., Hermy, M., \& Verheyen, K. (2012). Impact of mechanized harvesting on compaction of sandy and clayey forest soils: Results of a meta-analysis. Annals of Forest Science, 69(5), 533-542. 
Augusto, L., Dupouey, J.-L., \& Ranger, J. (2003). Effects of tree species on understory vegetation and environmental conditions in temperate forests. Annals of Forest Science, 60, 823-831.

Avila, A., Aguillaume, L., Izquieta-Rojano, S., García-Gómez, H., Elustondo, D., Santamaría, J. M., \& Alonso, R. (2017). Quantitative study on nitrogen deposition and canopy retention in Mediterranean evergreen forests. Environmental Science and Pollution Research, 1-14.

Baeten, L., Hermy, M., \& Verheyen, K. (2009). Environmental limitation contributes to the differential colonization capacity of two forest herbs. Journal of Vegetation Science, 20(2), 209-223.

Balvanera, P., Pfisterer, A. B., Buchmann, N., He, J. S., Nakashizuka, T., Raffaelli, D., \& Schmid, B. (2006). Quantifying the evidence for biodiversity effects on ecosystem functioning and services. Ecology Letters, 9(10), 1146-1156.

Barbier, S., Balandier, P., \& Gosselin, F. (2009). Influence of several tree traits on rainfall partitioning in temperate and boreal forests: A review. Annals of Forest Science, 66, 602 (11 pp.).

Barbier, S., Gosselin, F., \& Balandier, P. (2008). Influence of tree species on understory vegetation diversity and mechanisms involved-A critical review for temperate and boreal forests. Forest Ecology and Management, 254(1), 1-15.

Barkman, J.J., 1992. Canopies and microclimate of tree species mixtures. In: Cannell, M.G.R., Malcolm, D.C., Robertson, P.A. (Eds.), The Ecology of Mixed-species Stands of Trees. Blackwell Scientific Publications, Oxford, pp. $181-188$.

Battles, J. J., Shlinsky, A. J., Barrett, R. H., Heald, R. C., \& Allen-Diaz, B. H. (2001). The effects of forest management on plant species diversity in a Sierran conifer forest. Forest Ecology and Management, 146, 211-222.

Belyazid, S., Kurz, D., Braun, S., Sverdrup, H., Rihm, B., \& Hettelingh, J. P. (2011). A dynamic modelling approach for estimating critical loads of nitrogen based on plant community changes under a changing climate. Environmental Pollution, 159(3), 789-801.

Bernhardt-Römermann, M., Baeten, L., Craven, D., De Frenne, P., Hèdl, R., Lenoir, J., ... Verheyen, K. (2015). Drivers of temporal changes in temperate forest plant diversity vary across spatial scales. Global Change Biology, 21(10), 3726-3737.

Bierzychudek, P. (1982). Life Histories and Demography of Shade-Tolerant Temperate Forest Herbs : A Review. The New Phytologist, 90(4), 757-776.

Bodegom, P. M. Van, Douma, J. C., Witte, J. P. M., Ordoñez, J. C., Bartholomeus, R. P., \& Aerts, R. (2012). Going beyond limitations of plant functional types when predicting global ecosystem - atmosphere fluxes : exploring the merits of traits-based approaches. Global Ecology and Biogeography, 21, 625-636. 
597 Botkin, D. B., Janak, J. F., \& Wallis, J. R. (1972). Some Ecological Consequences of a Computer Model of Forest 598 Growth. Journal of Ecology, 60(3), 849-872.

599 Bratton, S. P. (1976). Resource Division in an Understory Herb Community: Responses to Temporal and 600 Microtopographic Gradients. The American Naturalist, 110(974), 679-693.

601 Bugmann, H. (2001). A review of forest gap models. Climate Change, 51, 259-305.

602 Chazdon, R. L., \& Pearcy, R. W. (1991). The Importance of Sunflecks for Forest Understory Plants. BioScience, $60341(11), 760-766$.

604 Clark, J. S. (2005). Why environmental scientists are becoming Bayesians. Ecology Letters, 8(1), 2-14.

605 Cramer, W. (1997). Using plant functional types in a global vegetation model. In: Smith, T., Shugart, H., 606 Woodward, F. I. (eds.) Plant functional types: their relevance to ecosystem properties and global change. 607 Cambridge, UK: Cambridge University Press, 271-288.

608 Cramer, W., Bondeau, A., Woodward, F. I., Prentice, I. C., Betts, R. A., Brovkin, V., ... Young-Molling, C. (2001). 609 Global response of terrestrial ecosystem structure and function to $\mathrm{CO} 2$ and climate change: Results from six 610 dynamic global vegetation models. Global Change Biology, 7(4), 357-373.

611 Dahlgren, J. P., \& Ehrlén, J. (2011). Incorporating environmental change over succession in an integral 612 projection model of population dynamics of a forest herb. Oikos, 120(8), 1183-1190.

613 Daws, M. I., Burslem, D. F. R. P., Crabtree, L. M., Kirkman, P., Mullins, C. E., \& Dalling, J. W. (2002). Differences 614 in seed germination responses may promote coexistence of four sympatric Piper species. Functional Ecology, 615 16(2), 258-267.

616 De Frenne, P., Rodríguez-Sánchez, F., Coomes, D. A., Baeten, L., Verstraeten, G., Vellend, M., ... Verheyen, K. 617 (2013). Microclimate moderates plant responses to macroclimate warming. Pnas, 110(46), 18561-5.

618 De Frenne, P., Rodríguez-Sánchez, F., De Schrijver, A., Coomes, D. a., Hermy, M., Vangansbeke, P., \& 619 Verheyen, K. (2015). Light accelerates plant responses to warming. Nature Plants, 1(9), 15110.

620 De Schrijver, A., Geudens, G., Augusto, L., Staelens, J., Mertens, J., Wuyts, K., ... Verheyen, K. (2007). The 621 effect of forest type on throughfall deposition and seepage flux a review. Oecologia, 153(3), 663-674.

622 De Schrijver, A., De Frenne, P., Staelens, J., Verstraeten, G., Muys, B., Vesterdal, L., ... Verheyen, K. (2012). 623 Tree species traits cause divergence in soil acidification during four decades of postagricultural forest 624 development. Global Change Biology, 18(3), 1127-1140. 
Díaz, S., Kattge, J., Cornelissen, J. H. C., Wright, I. J., Lavorel, S., Dray, S., ... Gorné, L. D. (2015). The global spectrum of plant form and function. Nature, 529(7585), 167-171.

Didham, R. K., Tylianakis, J. M., Gemmell, N. J., Rand, T. A., \& Ewers, R. M. (2007). Interactive effects of habitat modification and species invasion on native species decline. Trends in Ecology and Evolution, 22(9), 489-496.

Facelli, J. M., \& Pickett, S. T. A. (1991). Plant Litter: Its Dynamics and Effects on Plant Community Structure. Botanical Review, 57(1), 1-32.

Falkengren-Grerup, U., Brunet, J., \& Quist, M. E. (1995). Sensitivity of plants to acidic soils exemplified by the forest grass Bromus benekenii. Water, Air, and Soil Pollution, 85(3), 1233-1238.

Flinn, K. M., \& Marks, P. L. (2007). Agricultural Legacies in Forest Environments : Tree Communities, Soil Properties, and Light Availability. Ecological Applications, 17(2), 452-463.

Fontes, L., Bontemps, J., Bugmann, H., Oijen, M. Van, Kramer, K., Lindner, M., Rötzer, T. \& Skovsgaard, J. P. (2010). Models for supporting forest management in a changing environment. Forest Systems, 19(SI), 8-29.

Fotelli, M. N., Rennenberg, H., \& Geûler, A. (2002). Effects of drought on the competitive interference of an early successional species (rubus fruticosus) on fagus sylvatica L. seedlings: N15 uptake and partitioning, responses of amino acids and other $\mathrm{N}$ compounds. Plant Biology, 4, 311-320.

Fowler, D., Cape, J. N., \& Unsworth, M. H. (1989). Deposition of atmospheric pollutants on forests. Philosophical Transactions of the Royal Society of London B: Biological Sciences, 324(1223), 247-265.

Franklin, J., Serra-Diaz, J. M., Syphard, A. D., \& Regan, H. M. (2016). Global change and terrestrial plant community dynamics. Proceedings of the National Academy of Sciences, 113(14), 3725-3734.

Gale, M. R., \& Grigal, D. F. (1987). Vertical root distributions of nothern tree species in relation to successional status. Canadian Journal of Forest Research, 17, 829-834.

Gilliam, F. S. (2007). The Ecological Significance of the Herbaceous Layer in Temperate Forest Ecosystems. BioScience, 57(10), 845-858.

Grubb, P. J. (1977). the Maintenance of Species-Richness in Plant Communities: the Importance of the Regeneration Niche. Biological Reviews, 52(1), 107-145.

Harmer, R., \& Morgan, G. (2007). Development of Quercus robur advance regeneration following canopy reduction in an oak woodland. Forestry, 80(2), 137-149.

Harvey, L. D. D. (2000). Upscaling in global change research. Climatic Change, 44, 225-263. 
IPCC (2014). Climate Change 2014: Synthesis Report. Contribution of Working Groups I, II and III to the Fifth Assessment Report of the Intergovernmental Panel on Climate Change (Core Writing Team, R.K. Pachauri and L.A. Meyer (eds.)). IPCC, Geneva, Switzerland, 151 pp.

Jankowska-Blaszczuk, M., \& Daws, M. I. (2007). Impact of red: Far red ratios on germination of temperate forest herbs in relation to shade tolerance, seed mass and persistence in the soil. Functional Ecology, 21(6), 1055-1062.

Jeltsch, F., Moloney, K. A., Schurr, F. M., Köchy, M., \& Schwager, M. (2008). The state of plant population modelling in light of environmental change. Perspectives in Plant Ecology, Evolution and Systematics, 9(3-4), 171-189.

Jorgensen, S. E. (2011). Handbook of ecological models used in ecosystem and environmental management. (S. E. Jorgensen, Ed.). Boca Raton: CRC Press.

Kattge, J., Díaz, S., Lavorel, S., Prentice, I. C., Leadley, P., Bönisch, G., ... Wirth, C. (2011). TRY - a global database of plant traits. Global Change Biology, 17, 2905-2935.

Keith, D. A., Holman, L., Rodoreda, S., Lemmon, J., \& Bedward, M. (2007). Plant functional types can predict decade-scale changes in fire-prone vegetation. Journal of Ecology, 95(6), 1324-1337.

Kellomäki, S., \& Väisänen, H. (1991). Application of a gap model for the simulation of forest ground vegetation in boreal conditions. Forest Ecology and Management, 42(1-2), 35-47.

Khanina, L., Bobrovsky, M., Komarov, A., \& Mikhajlov, A. (2007). Modeling dynamics of forest ground vegetation diversity under different forest management regimes. Forest Ecology and Management, 248(12), 80-94.

Kumar, P., \& Chen, H. Y. H. (2017). Linking resource availability and heterogeneity to understorey species diversity through succession in boreal forest of Canada. Journal of Ecology, 1-11.

Kumar, P., Chen, H. Y. H., Thomas, S. C., \& Shahi, C. (2017). Effects of coarse woody debris on plant and lichen species composition in boreal forests. Journal of Vegetation Science, 28, 389-400.

Kupferschmid, A. D., \& Bugmann, H. (2005). Predicting Decay and Ground Vegetation Development in Picea abies Snag Stands. Plant Ecology, 179(2), 247-268.

Lang, C., Seven, J., \& Polle, A. (2011). Host preferences and differential contributions of deciduous tree species shape mycorrhizal species richness in a mixed Central European forest. Mycorrhiza, 21, 297-308.

Li, D., \& Waller, D. (2015). Drivers of observed biotic homogenization in pine barrens of central Wisconsin. Ecology, 96(4), 1030-1041. 
Lieffers, V. J., Messier, C., Stadt, K. J., Gendron, F., \& Comeau, P. G. (1999). Predicting and managing light in the understory of boreal forests. Canadian Journal of Forest Research, 29(6), 796-811.

Maes, S. L., De Frenne, P., Brunet, J., de la Peña, E., Chabrerie, O., Cousins, S. A. O., ... Verheyen, K. (2014). Effects of enhanced nitrogen inputs and climate warming on a forest understorey plant assessed by transplant experiments along a latitudinal gradient. Plant Ecology, 215(8), 899-910.

Manusch, C., Bugmann, H., Heiri, C., \& Wolf, A. (2012). Tree mortality in dynamic vegetation models - A key feature for accurately simulating forest properties. Ecological Modelling, 243, 101-111.

Matejicek, L., Vavrova, E., \& Cudlin, P. (2011). Spatio-temporal modelling of ground vegetation development in mountain spruce forests. Ecological Modelling, 222(14), 2584-2592.

Meen, E., Nielsen, A., \& Ohlson, M. (2012). Forest stand modelling as a tool to predict performance of the understory herb Cornus suecica. Silva Fennica, 46(4), 479-499.

Meiyappan, P., Dalton, M., O'Neill, B. C., \& Jain, A. K. (2014). Spatial modeling of agricultural land use change at global scale. Ecological Modelling, 291, 152-174.

Millenium Ecosystem Assessment (2005). Ecosystems and human well-being: Synthesis. Washington DC: Island Press.

Monserud, R. a., \& Sterba, H. (1996). A basal area increment model for individual trees growing in even- and uneven-aged forest stands in Austria. Forest Ecology and Management, 80(1-3), 57-80.

Monsi, M., \& Saeki, T. (2005). On the factor light in plant communities and its importance for matter production. Annals of Botany, 95(3), 549-567.

Muukkonen, P., \& Mäkipää, R. (2006). Empirical biomass models of understorey vegetation in boreal forests according to stand and site attributes. Boreal Environment Research, 11(5), 355-369.

Nabuurs, G. J. (1996). Quantification of herb layer dynamics under tree canopy. Forest Ecology and Management, 88(1-2), 143-148.

Neumann, R. B., \& Cardon, Z. G. (2012). The magnitude of hydraulic redistribution by plant roots : a review and synthesis of empirical and modeling studies. New Phytologist, 194, 337-352.

Nilsson, S. I., Miller, H. G., \& Miller, J. D. (1982). Nordic Society Oikos Forest Growth as a Possible Cause of Soil and Water Acidification : An Examination of the Concepts. Oikos, 39(1), 40-49.

Noble, I. R., \& Slatyer, R. O. (1980). The Use of Vital Attributes to Predict Changes in Plant Communities Subject to Recurrent Disturbances. Vegetatio, 43(1-2), 5-21. 
Pappas, C., Fatichi, S., \& Burlando, P. (2016). Modeling terrestrial carbon and water dynamics across climatic gradients: Does plant trait diversity matter? New Phytologist, 209, 137-151.

Parker, W. C., Pitt, D. G., \& Morneault, A. E. (2009). Influence of woody and herbaceous competition on microclimate and growth of eastern white pine (Pinus strobus L.) seedlings planted in a central Ontario clearcut. Forest Ecology and Management, 258(9), 2013-2025.

Perring, M. P., De Frenne, P., Baeten, L., Maes, S. L., Depauw, L., Blondeel, H., ... Verheyen, K. (2016). Global environmental change effects on ecosystems: The importance of land-use legacies. Global Change Biology, 22(4), 1361-1371.

Petriţan, I. C., von Lüpke, B., \& Petriţan, A. M. (2012). Response of planted beech (Fagus sylvatica L.) and Douglas-fir (Pseudotsuga menziesii (Mirb.) Franco) saplings to herbaceous and small shrubs control on clearcuts. Journal of Forest Research, 17(2), 164-174.

Popovic, Z. S., \& Lindquist, J. L. (2010). Evaluation of the intercom model for predicting growth of forest herbs. Archives of Biological Sciences, 62(1), 175-184.

Porté, A., Huard, F., \& Dreyfus, P. (2004). Microclimate beneath pine plantation, semi-mature pine plantation and mixed broadleaved-pine forest. Agricultural and Forest Meteorology, 126(1-2), 175-182.

Reineking, B., Veste, M., Wissel, C., \& Huth, A. (2006). Environmental variability and allocation trade-offs maintain species diversity in a process-based model of succulent plant communities. Ecological Modelling, 199(4), 486-504.

Roberts, M. R., \& Gilliam, F. S. (2003). Response of the herbaceous layer to disturbance in eastern forests. The herbaceous layer in forests of eastern North America. Oxford University Press, Oxford (2003): 302-320.

Rooney, T. P., \& Waller, D. M. (2003). Direct and indirect effects of white-tailed deer in forest ecosystems. Forest Ecology and Management, 181(1-2), 165-176.

Sala, O. E., Chapin III, F. S., Armesto, J. J., Berlow, E., Bloomfield, J., Dirzo, R., ... Wall, D. H. (2000). Global Biodiversity Scenarios for the Year 2100. Science, 287, 1770-1774.

Seidl, R., Schelhaas, M.-J., \& Lexer, M. J. (2011a). Unraveling the drivers of intensifying forest disturbance regimes in Europe. Global Change Biology, 17, 2842-2852.

Seidl, R., Fernandes, P. M., Fonseca, T. F., Gillet, F., Jönsson, A. M., Merganičová, K., ... Mohren, F. (2011b). Modelling natural disturbances in forest ecosystems: A review. Ecological Modelling, 222(4), 903-924.

Seidl, R., Schelhaas, M.-J., Rammer, W., \& Verkerk, P. J. (2014). Increasing forest disturbances in Europe and their impact on carbon storage. Nature Climate Change, 4(9), 806-810. 
Seidl, R. (2017). To Model or not to Model, That is no Longer the Question for Ecologists. Ecosystems, 20, 222-228.

Seto, K. C., Güneralp, B., \& Hutyra, L. R. (2012). Global forecasts of urban expansion to 2030 and direct impacts on biodiversity and carbon pools. Proceedings of the National Academy of Sciences of the United States of America, 109(40), 16083-16088.

Simioni, G., Roux, X. Le, Gignoux, J., \& Sinoquet, H. (2000). Treegrass : a 3D process-based model for simulating plant interactions in tree - grass ecosystems, 131, 47-63.

Staelens, J., De Schrijver, A., Verheyen, K., \& Verhoest, N. E. C. (2006). Spatial variability and temporal stability of throughfall water under a dominant beech ( Fagus sylvatica L .) tree in relationship to canopy cover, 651662. http://doi.org/10.1016/j.jhydrol.2006.04.032

Staelens, J., De Schrijver, A., Verheyen, K., \& Verhoest, N. E. C. (2008). Rainfall partitioning into throughfall, stemflow, and interception within a single beech (Fagus sylvatica L.) canopy: influence of foliation, rain event characteristics, and meteorology. Hydrological Processes, 22, 33-45.

Suding, K. N., Lavorel, S., Chapin III, F. S., Cornelissen, J. H. C., Diaz, S., Garnier, E., ... Navas, M.-L. (2008). Scaling environmental change through the community-level: a trait-based response-and-effect framework for plants. Global Change Biology, 14, 1125-1140. http://doi.org/10.1111/j.1365-2486.2008.01557.x

Taubert, F., Frank, K., \& Huth, A. (2012). A review of grassland models in the biofuel context. Ecological Modelling, 245, 84-93.

Thom, D., Rammer, W., Dirnböck, T., Müller, J., Kobler, J., Katzensteiner, K., Helm, N., Seidl, R. 2017. The impacts of climate change and disturbance on spatio-temporal trajectories of biodiversity in a temperate forest landscape. Journal of Applied Ecology, 54, 28-38.

Thornley, J. H. M., \& Johnson, I. R. (1990). Plant and crop modelling: A mathematical approach to plant and crop physiology. The Blackburn Press. Caldwell, New Jersey. pp. 669

Thrippleton, T., Bugmann, H., Kramer-priewasser, K., \& Snell, R. S. (2016). Herbaceous Understorey : An Overlooked Player in Forest Landscape Dynamics? Ecosystems, 19, 1240-1254.

Tietjen, B. (2016). Same rainfall amount different vegetation - How environmental conditions and their interactions influence savanna dynamics. Ecological Modelling, 326, 13-22.

Tilman, D. (1982). Resource Competition and Community Structure. Princeton University Press, Princeton, NJ.

Tylianakis, J. M., Didham, R. K., Bascompte, J., \& Wardle, D. A. (2008). Global change and species interactions in terrestrial ecosystems. Ecology Letters, 11(12), 1351-1363. 
Uibopuu, A., Moora, M., Öpik, M., \& Zobel, M. (2012). Temperate forest understorey species performance is altered by local arbuscular mycorrhizal fungal communities from stands of different successional stages. Plant Soil, 356, 331-339.

Van Miegroet H., \& Cole D. W. (1984) The impact of nitrification on soil acidification and cation leaching in a Red alder ecosystem. J Environ Qual 13(4), 586-590.

Vazquez-yanes, C., Orozco-Segovia, A., Rincón, E., Sánchez-Coronda, P., Huante, J. R., Toledo, J. R., \& Barradas, V. L. (1990). Light Beneath the Litter in a Tropical Forest : Effect on Seed Germination. Ecology, 71(5), 1952-1958.

Verheyen, K., Baeten, L., De Frenne, P., Bernhardt-Römermann, M., Brunet, J., Cornelis, J., ... Verstraeten, G. (2012). Driving factors behind the eutrophication signal in understorey plant communities of deciduous temperate forests. Journal of Ecology, 100(2), 352-365.

Verheyen, K., De Frenne, P., Baeten, L., Waller, D. M., Hédl, R., Perring, M. P., ... Bernhardt-Römermann, M. (2017). Combining Biodiversity Resurveys across Regions to Advance Global Change Research. BioScience, 67(1), 73-83.

Violle, C., Navas, M.-L., Vile, D., Kazakou, E., Fortunel, C., Hummel, I. and Garnier, E. (2007), Let the concept of trait be functional!. Oikos, 116: 882-892.

Vospernik, S., Bokalo, M., Reimoser, F., \& Sterba, H. (2007). Evaluation of a vegetation simulator for roe deer habitat predictions. Ecological Modelling, 202(3-4), 265-280.

Way, D. A., \& Pearcy, R. W. (2012). Sunflecks in trees and forests: From photosynthetic physiology to global change biology. Tree Physiology, 32(9), 1066-1081.

Winkler, E., \& Heinken, T. (2007). Spread of an ant-dispersed annual herb: An individual-based simulation study on population development of Melampyrum pratense L. Ecological Modelling, 203(3-4), 424-438.

Wright, I. J., Reich, P. B., Westoby, M., Ackerly, D. D., Baruch, Z., Bongers, F., ... Villar, R. (2004). The worldwide leaf economics spectrum. Nature, 428, 821-827.

Xiong, S., \& Nilsson, C. (1999). The effects of plant litter on vegetation: A meta-analysis. Journal of Ecology, 87(6), 984-994.

Zenner, E. K., \& Berger, A. L. (2008). Forest Ecology and Management Influence of skidder traffic and canopy removal intensities on the ground flora in a clearcut-with-reserves northern hardwood stand in Minnesota, USA, 256, 1785-1794. 